\title{
POVERTY AS A CHALLENGE TO WEALTH IN HOMER'S ODYSSEY
}

\section{$R$ Whitaker (University of Cape Town)}

This article examines the ways in which poverty, as a condition, and as represented by poor individuals, poses a challenge to wealthy, elite characters in the Odyssey. Great, almost revolutionary, changes took place in Greece in the eighth century BC, when the Odyssey was most likely composed. The audience of the epic, it is argued, comprised both wealthy, elite and poor, non-elite persons. The bases of wealth and poverty in the Odyssey were land, or the lack of it. Reflecting the instability of the eighth century, the Odyssey repeatedly presents a fall into poverty as a very real, challenging possibility for wealthy individuals. In the epic, the presence of poverty in their midst, as represented by the 'beggar' (Odysseus in disguise), tests the humanity and compassion of the characters whom he meets. The suitors fail the test, reacting with cruelty and contempt to the poor man. Eumaios and Penelope rise to the challenge, showing pity and generosity of spirit. The Odyssey thus indicates that moral goodness is independent of wealth and status, and that pity and compassion are the appropriate responses to the poor.

Keywords: Odyssey; archaic Greece; audience; wealth; poverty; pity; compassion.

In this article I discuss the ways in which poverty, as represented by poor and destitute individuals, presents a challenge to the values and attitudes of elite, wealthy persons in Homer's Odyssey. Since issues of this kind clearly arise out of, and reflect, the world from which the epic came, I shall begin by summarizing what I think to have been the social and historical context within which the Odyssey was composed and performed.

In my view, our Odyssey was composed and fixed in writing in the late eighth century, or possibly the early seventh century BC. ${ }^{1}$ Now most historians and archaeologists agree that the eighth century, in Greece, was a period of great even revolutionary - change. Populations grew rapidly, as did economic activity, such as it was. In the eighth century the polis first began to develop, as a physical layout and as a political community. Assemblies rose in importance, and the power of elites was curtailed. Within the nascent polis, the dèmos, the body of adult male

For the dating of the Homeric epics, see Graziosi $2002 \mathrm{ch}$. 3, with the literature cited there; Ulf 2009:81-83, who acutely points out how critics' views about the manner of composition of the epics influence their conclusions about dating; West 2011:389-393. 
citizens, including poor ones, now had at least some say in how they were governed. Since people hardly ever cede power without a struggle, one assumes that these great political changes were hotly contested. ${ }^{2}$

This, then, was the context for our Odyssey. Whether the poet - let us call him 'Homer' - dictated his poem to a scribe or wrote it down himself is not important for our purposes. What is of great importance, though, is that the Odyssey was composed for, and achieved its impact only through, oral performance. But everything we know from comparative studies of oral poetry tells us that the audience is an integral part of such a performance, and that performance is something negotiated between audience and performer. ${ }^{3}$ However skilled and creative the oral poet, if he does not deal with things that are of concern to, and that move his listeners, he will lose those listeners and his poem will fail. ${ }^{4}$

This provides us with a vital clue as to the first audiences of the Odyssey. Given that the poet had to appeal to them and to hold their attention, we can, I believe, work backwards from the subject matter and concerns of the epic to gain at least some notion of the people who listened to it. The elite certainly comprised a significant part of the Odyssey's audience. We can see this from the poem's extensive, sympathetic portrayal of the graceful and leisurely way of life of Menelaos, Nestor and the Phaiakians. This is not to say that Homer is uncritical of his elite characters: he portrays Menelaos as sometimes obtuse; ${ }^{5}$ Nestor can be too pressing a host $;{ }^{6}$ one of the gilded Phaiakian youths boorishly insults Odysseus. ${ }^{7}$ And of course the elite suitors, 'the leading chieftains of the islands' (Od. 1.245), are condemned out of hand for the arrogant, violent behaviour that, in the end, brings about their destruction.

Nevertheless, though they may be criticized, the poet never imagines a human world where the elite do not lead society. The ideal that the Odyssey

2 On social, economic and political developments in the eighth-century Greek world, see Morris 1986:94-115; Thalmann 1998:243-271; Morris 2007; Morris 2009; Crielaard 2009; Ulf 2009.

3 Morris 1986:83-94. As Dalby 1995:269-270 points out, there are actually examples in the Odyssey itself of negotiation between audience and singer; e.g. Od. 8.487-498.

4 Morris 1986:85-87; Thalmann 1988:26.

5 Menelaos sets, first, his guest Telemakhos, and then the whole company weeping (Od. 4.104-116 and 183-186), and his wife Helen has to save the day by giving them all a tranquilising drug (4.219-221); later, Telemakhos has to point out that the gift of horses Menelaos has offered him is unsuitable for Ithaka (4.600-608).

6 On his return to Pylos, Telemakhos avoids the too-insistent hospitality of Nestor (Od. 15.193-201).

7 Od. 8.158-166. 
presents to its audience is that of a righteous, paternal ruler: '[a] noble god-fearing chief, / ruler over many powerful men, / upholder of justice' (Od. 19.109-111). ${ }^{8}$

But the Odyssey by no means speaks only to the elite. Many elements particularly in the second half of the epic - suggest that its audience included poorer, humbler people to whom, also, the performance had to appeal. ${ }^{9}$ Among the more sympathetic characters in the poem are Odysseus' housekeeper Eurykleia, and the herdsmen Eumaios and Philoitios. And servants, slaves and beggars do not always remain quietly in the background, they are sometimes allowed to speak at length and to express the viewpoint and the concerns of the non-elite. ${ }^{10}$ For instance, the 'beggar' (Odysseus in disguise) challenges the high-born Eurymakhos to a contest of agricultural tasks:

Eurymakhos, I'd like to see the two of us compete working the land in spring, when days grow long, cutting grass, me with a curving sickle, you likewise, the grass deep, and see who worked the harder, without food, right till darkness came

(Od. 18.366-370).

It is easy to believe that humbler members of the audience would have been delighted to hear their manual skills praised by a 'beggar' at the expense of a noble who lacked those skills. ${ }^{11}$ So too, when Eumaios says

But servants love to chat, to talk each thing over with their mistress, and eat and drink, and have something to take home to the fields - such things warm a servant's heart

(Od. 15.376-379).

8 All Odyssey translations (sometimes slightly adapted) are from Whitaker 2017. For the just ruler, $c f$. the parallel passage in Hesiod WD 225-237, where the emphasis is more on justice than on the ruler.

9 I would not fully agree with Finley's blunt statement: 'What we have [in the Homeric epics] ... are the morals and values of a warrior culture, and with that we must be content' (Finley 2002:115; similarly Strasburger 1997:55, 'There is probably complete agreement ... that the Homeric poems stem from an aristocratic world'). By contrast, Dalby 1995:279 assumes that Homer's audience consisted only of poor people, while Rose 1975:146 says, 'it is likely, if not provable, that [the audience of the Odyssey] would most often be peasants'. My view is that the Odyssey's audience was a mixture of elite and non-elite, and I believe that we can get at least some idea from the Odyssey of the 'morals and values' of humbler individuals (cf. Thalmann 1988:2-3).

10 For non-elite elements in the Odyssey, see Donlan 1973:151-154.

11 The issue is, however, complicated by the fact that here one member of the elite (in disguise) challenges another; for the ironies and ideological complexities of the 'beggar's' exchange with Eurymakhos, see the acute discussion of Edwards 1993:70-76. 
or when a worn-out servant-woman curses the suitors and declares that grinding their barley has done for her knees (Od. 20.115-119), we seem to hear simple people speaking of their own concerns in ways that might have appealed to their counterparts in the audience.

To summarize my brief opening remarks: it is against a background of great political and social change, and to an audience including rich and poor, that I envisage the Odyssey raising its issues of poverty and wealth. With this in mind, let us look at what constitutes 'wealth' and 'poverty' in the epic, and then at how the latter serves as a challenge to the former.

Wealth in the Odyssey derives directly from land, the animals it can sustain, and the grain and fruit it can produce. Eumaios says of Odysseus that the hero's 'livelihood was vast', 'he had the wealth / of twenty men at least', consisting of fifty-nine herds in total of cattle, pigs, sheep and goats (Od. 14.96-104). In the orchard worked by Odysseus' father Laertes, fruit trees, vines, olives and greens are mentioned (Od. 24.346-347). One assumes that the contents of Odysseus' storeroom described in $\mathrm{Od}$. Book 2 are the products of his own lands, together with goods obtained by barter using his agricultural surplus. We hear of 'bronze', 'gold', 'chests of clothing', 'scented olive oil' and 'pots of sweet vintage wine' (Od. 2.337-341).

The rich man's wealth meant that he did not have to work. Instead, he controlled the activities of numerous dependent labourers and slaves who herded his animals, worked his fields, served his household, spun thread and wove cloth. Another - one assumes less common - way of acquiring wealth was through piracy and raiding. A prime instance of this would be the Cretan persona of Odysseus, who declares: 'I'd led nine separate bands of men in ships / on raids abroad, and great wealth came my way. /... My homestead grew' (Od. 14.230233).

What of the poor man? When Akhilleus in Odyssey Book 11 speaks of the most wretched individual he can think of, his imagination conjures up one who is bound to work for another who is himself landless. Akhilleus declares:

I'd rather be the serf of some landless

man without much livelihood, on earth,

than lord over all the dead and gone

(Od. 11.388-391).

(This shows, by contrast, the absolute dependence on land of wealth and wellbeing). Without land, a poor man cannot feed, house or clothe himself - he

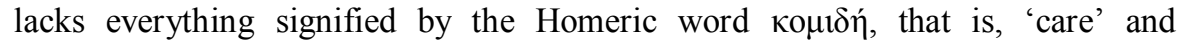
'sustenance'.

In the Odyssey, the best example of a poverty-stricken person is the hero himself in his beggar's disguise. The 'beggar' speaks of 'vagrancy' as the 'worst 
thing of all for mortals' (Od. 15.343). It hardly needs saying that a destitute vagrant is landless and homeless. The poem suggests that the most a tramp could hope for would be temporary shelter in a wealthy homestead (as Odysseus, disguised as a beggar, is sheltered in his own home from Book 19 on), or at a blacksmith's forge where there would at least be a warming fire, or at the $\lambda \dot{\varepsilon} \sigma \chi \eta$, the place where men gathered for leisurely conversation (Od. 18.328-329). As for clothing, the 'beggar' is meagrely dressed in a tunic full of holes and a hairless deerskin, insufficient to ward off the cold (Od. 13.434-437; 14.457-461); he is apparently barefoot, as there is no mention of footwear. The 'beggar' is several times promised more adequate garments, 'a cloak and tunic', and once 'sandals for his feet', indicating what he sorely lacks (Od. 14.515-516; 21.339-341, and elsewhere). ${ }^{12}$

But the thing that most starkly defines the 'beggar's' poverty is hunger, the ever-present threat of starvation. Hesiod puts this very bluntly in a related context: 'starvation waits on the man who does not work' (WD 302). ${ }^{13}$ In the Odyssey, when the tramp goes to town he does not expect to be given more than the barest essentials of life, 'a drink and bread' (Od. 15.311-312). In addition, the poem repeatedly lays emphasis on 'the belly' and the suffering caused by extreme hunger: 'But no one can contain the belly - raging, / deadly, that brings great suffering on men' (Od. 17.286-287). ${ }^{14}$

We are now in a position to discuss what Homer does with these notions, how, in the words of my title, poverty acts in certain ways as a challenge to wealth in the Odyssey. This occurs especially, and most extensively, in the second half of the epic. First, we shall see that the Odyssey presents the state of poverty and destitution, not as some distant prospect from which the elite are far removed or insulated, but as an ever-present threat, a condition to which anyone may easily be reduced..$^{15}$ Second, I will look at the ways in which poverty, represented by the destitute beggar, challenges the generosity and compassion of the elite (and, in one instance, non-elite) members and occupants of Odysseus' homestead. To me it is very striking that, under both these aspects, the Odyssey seems to indicate that human worth is not ultimately dependent upon wealth or the status that derives

12 Note, too, at $O d .3 .348-349$ Nestor's indignant rejection of the idea that his home might

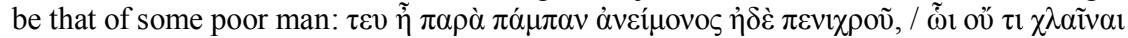

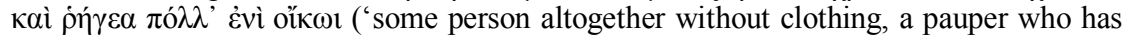
no blankets and few sheets [lit. 'cloaks and cloths'] in his home').

13 In fact, the ever-present threat of hunger and starvation is a leitmotif in Hesiod's Works and Days: WD 363; 403-404; 647.

${ }_{14}$ Cf. Od. 7.215-21; 15.344-345; 17.473-474, 558-559; 18.53-54, 380.

15 This likely reflects historical reality: Whitley 1991:347-352 emphasises the instability of some Dark Age Greek communities, especially those dependent on the so-called 'big man' system. Hesiod, too, emphasizes the narrow margin between prosperity and destitution in his world; see e.g. WD 349-351; 390-400. 
from it; and that a sense of humanity, and pity for suffering, are the appropriate responses to the poor.

The second half of the Odyssey offers us many examples of people from wealthy households suddenly confronted by poverty. One instance of such a person is Odysseus' swineherd, Eumaios, whose father ruled over two towns, together with their lands, 'rich in flocks and cattle, wine and wheat' (Od. 15.406; we note, incidentally, the purely agricultural basis of the father's wealth). But Eumaios' nurse stole him as a child from his prosperous home and sold him into slavery (Od. 15.403-484). ${ }^{16}$

The Cretan persona adopted by Odysseus when disguised as a beggar offers several more instances of a sudden fall from prosperity into destitution. In Book 14 the 'Cretan' tells us he gained great wealth, but lost everything in a shipwreck (Od. 14.285-315). Not long afterwards, when he had been rescued and clothed, a ship's crew 'worked out my day of slavery for me'; they 'took away my tunic, cloak and clothing' and 'dressed me in a shabby, ragged tunic / full of holes' (Od. 14.339-343). In Book 17 the 'beggar' tells of a similar reversal of fortune:

For I ... once was rich and lived in a wealthy home ...

And I had countless servants and everything the prosperous and those thought wealthy have.

But Zeus took it all away - that was his will

(Od. 17.419-424; repeated at 19.75-80).

Again, in his interview with Penelope, the 'beggar' - although he does not say how he came to his present, impoverished state - claims to have once been a wealthy Cretan (Od. 19.172ff., with 195). We might also instance the rich Odysseus himself and his household whom the all-devouring suitors are threatening to reduce to penury.

Given all these instances in the Odyssey, I would suggest that, due to the turbulence and instability of the eighth century and early archaic period in Greece, the sight of vagabonds, some of them once-prosperous individuals fallen on hard times and forced to beg, must have been familiar to epic audiences. ${ }^{17}$ That such poverty-stricken figures challenged the wealthy elite and demanded a response

16 The nurse herself, too, is an example of radical change of fortune; she came, so she says, from a wealthy home, but became a slave after she was snatched by raiders (Od. 15.425-429).

17 In the Odyssey, besides the 'beggar' / Odysseus and Iros (Od. 18.1-7), it seems that many vagabonds have come to Ithaka, spinning their stories in hope of a meal; $c f$. Eumaios' words at $O d$. 14.122-128. Hesiod also implies that formerly prosperous people often fall into want; $c f$. the passages of $W D$ cited above in $n .15$. 
from them, is also suggested by the poem. This brings me to the second part of my discussion.

The suitors in the Odyssey are wealthy men. In Book 20, the poet says:

Among the suitors, there was a lawless man,

... Ktesippos by name,

who, made bold by his enormous wealth,

wooed the wife of Odysseus ...

(Od. 20.287-290).

Earlier, in Book 18, all the young men were able to give Penelope luxury items as gifts (Od. 18.291-301). But, despite their wealth, confronted by the poor, tattered 'beggar' in Odysseus' home, the suitors fail dismally in their reactions to him. This is primarily a failure to observe the obligations of $\xi \varepsilon v i ́ n$, guest-friendship something I do not have the space to examine here. ${ }^{18}$ But it is also a failure of simple humanity and compassion towards the poor. ${ }^{19}$ The presence of a destitute man at their lavish feasts makes the suitors uncomfortable. When Eumaios accompanies the 'beggar' into the hall, the violent, arrogant leader of the suitors, Antinoös, abuses both of them:

Infamous swineherd, why did you bring this man

to town? Don't we have enough vagabonds

and annoying tramps, the scavengers of meals?

Did you think there were too few to guzzle

your master's food, that you brought this one as well? (Od. 17.376-379).

A little while later, Antinoös abuses the 'beggar' directly:

What god brought this curse to spoil our feast?

Stand in the middle, get away from my table ...

(Od. 17.446-447).

On this occasion, the other suitors show a measure of humanity. Approached by the 'beggar', we are told, they 'felt pity, ${ }^{20}$ gave and, wondering at him, / asked each other who he was and whence he came' (Od. 17.367-368). But at the next day's meal, the suitors in general are disturbed by his presence:

18 Hospitality in the Odyssey has been much discussed; $c f$. Donlan 1982:148-151; Heubeck et al. 1988-1992: General Index, under 'hospitality' and 'typical scenes: reception of visitor'; Finley 2002:99-104, 123-128; Saïd 2011:367-372.

19 The correct response is stated by Odysseus himself (in beggar's disguise) in his speech to Antinoös: 'For I, too, once was rich and lived in / a wealthy home and often gave to beggars / like myself, whatever they were, or needed' (Od. 17.419-421).

20 Another occasion on which all other suitors, with the sole exception of Antinoös, show pity is $O d .2 .80-84$. 
and each, glancing at his neighbour, said:

'I wish the wandering stranger had died elsewhere

and not come here ...

We're quarrelling over beggars; we can't enjoy

our feast if the worse element prevails'

(Od. 18.400-404).

The response, though, of the elite suitors towards poverty-stricken beggars goes well beyond mere unease. They behave towards these poor men, their social 'inferiors', as if they were less than human, mere objects, to be treated with contempt, mocked, insulted and assaulted. A mild instance of this is when Eurymakhos (to be echoed by elite opinion throughout the ages) insultingly suggests that the 'beggar' is poor and hungry only because he is work-shy: 'you've learned bad habits, you won't want to work - / you'd rather go and cringe around the town / and beg for food' $(O d .18 .362-364=17.226-228) .{ }^{21}$ Much worse, at the start of Book 18 the suitors find it hugely amusing to have the 'beggar'/ Odysseus fight another beggar, the loutish Iros, with a prize of food for the winner. When the 'beggar' smashes Iros's jaw, the 'suitors raised their hands / and almost died from laughter' $\left(O d\right.$. 18.99-100). ${ }^{22}$

Challenged by the presence of the destitute beggar, the suitors show themselves to be uncaring and insensitive. To me it is very striking that, in the Odyssey, the suitors are never once said to have suffered themselves, and so they lack the empathy and imagination to identify with the unfortunate. Aristotle in the Rhetoric could almost be describing the suitors when he says: '[incapable of pity are] those who think that they are extremely fortunate, but are in fact arrogant. For if they think they have everything good, clearly they expect that nothing bad

21 On this passage, see Scodel 2005:405-406; Edwards 1993:46, 70. The other suitors abuse the beggar in similar terms at $O d$. 20.377-379: 'this dirty vagrant, / starving for food and wine, but useless / for work, feeble, just a burden on the earth'. This attitude is also more or less that of Hesiod, for whom the rich gain their wealth only by unremitting toil, while the destitute are poor because of their refusal to work (WD 298-316, 390404; by contrast, though, WD 716-717 says one should not reproach a man for his poverty, because this is a 'gift' of the gods).

22 This elite abuse of the poor for entertainment finds a precise, unpleasant parallel in the contemporary USA, in the so-called 'bum fights' described by the website Menstuff.org: 'It seems that ... heartless men are preying on the desperation of homeless men. Called Bumfights.com, these uncaring men pay homeless men to fight each other ... [they] are videotaped and the tapes are then sold ... [The] Las Vegas filmmakers ... recent graduates of ... film schools ... have marketed the work ... as a "hilariously shocking" look at "drunk bums fighting", (www.menstuff.org/archives/bumfights.html, accessed 07/09/2020). 
will happen to them'. ${ }^{23}$ By contrast, characters of the Odyssey who have suffered greatly show sympathy for the poor 'beggar', and treat him with compassion and generosity. We will look briefly at the responses of Eumaios, then Penelope.

In the world of the Odyssey, Eumaios is not among the poorest of the poor - he does, after all, own a slave (Od. 14.449-452), and he has access to Odysseus' herds and the protection of being a member of the hero's household. Nevertheless, the swineherd is in no sense a rich man. He has only an improvised couch of brushwood for his guest to sit on, a wooden bowl to mix wine in, and a single spare cloak to keep him warm. ${ }^{24}$ But although Eumaios is poor, his life of suffering (I touched earlier on the fact that he had been sold into slavery as a child) has made him readily sympathetic to the pain of others. When the stranger arrives, Eumaios' first words to him concern his (Eumaios') feelings of 'grief and pain' for the absent Odysseus, and he immediately invites the 'beggar' to come inside, to eat and drink 'and tell me ... what you've suffered' (Od. 14.39-47). ${ }^{25}$ The swineherd shows a full awareness of the sanctity of any destitute stranger, when he says to the 'beggar':

Friend, it's wrong to dishonour a stranger - even

a poorer man than you - for they all come from Zeus,

beggars and strangers, and to help them

costs us little

(Od. Book 14.56-59).

The hospitality that Eumaios then goes on to show his poor guest is exemplary of its kind.

Finally, the failure of the elite suitors to respond to the challenge of the 'beggar's' poverty, is shown up by the response of another member of the elite, namely Penelope. The wife of Odysseus has herself endured great suffering. On one occasion she declares: 'Zeus has given me more pain / than any woman born and raised with me' (Od. 4.722-723). And this experience of pain, as with

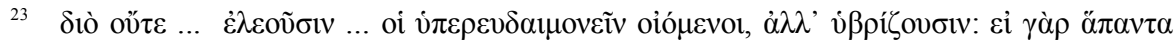

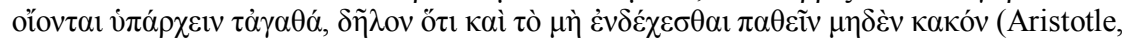
Rhet. 2.8 .3 [1385b]). Nussbaum 1994:87 underlines Aristotle's point about arrogance excluding pity: 'People who think they are above suffering and have everything will not, he says, have pity. Aristotle is not at all friendly to this state of mind: he twice refers to it as hubris (1385b21-22, b31)'. Carr 1999 provides a thoughtful discussion of Aristotle's account of pity and compassion in the Rhetoric. For a general survey of pity in Homer, see Scott 1979.

24 Couch of brushwood: Od. 14.39-40; wooden bowl: 14.78; single spare cloak: 14.513$514,520-522$.

$25 C f$. the very similar pattern of the sympathetic herdsman Philoitios' first response to the 'beggar', at Od. 20.185-225: spontaneous pity for the beggar's suffering, and a friendly greeting (194-200); indignation that Zeus does not pity suffering humanity (201-203); sorrow for the absent Odysseus (204-210); mention of his own pain (220-223). 
Eumaios and Philoitios, makes her sympathize with the poor stranger. Even before Penelope meets the 'beggar', when she is told how he has been mistreated in her house by Antinoös, she expresses outrage against the suitors' ringleader and pity for his victim. Penelope does not assume that the ragged wanderer is work-shy, or a nuisance at the feast, but says rather: 'Destitution drove this unhappy stranger / to roam about the hall and beg from men' (Od. 17.501-502). Told that the 'beggar' would prefer to meet her later, after dark, Penelope responds with empathetic understanding: 'Is the wanderer worried, / or too timid, or somehow ashamed to be / inside the house?' (Od. 17.576-578). When at last Penelope is face to face with the 'beggar', in Book 19, she receives him with great sympathy and tact, as an equal, despite his rags, and offers him a bath, clothes, and warm bedding.

When members of the elite receive one another, it could be (and has been) argued that generosity has an ulterior motive: hospitality and gifts are given with the expectation that they will be reciprocated. ${ }^{26}$ Menelaos, for instance, in Od. Book 15, suggests to Telemakhos that they make a tour of 'Hellas and all Argos', and

no one will send

us off empty-handed, but will give some gift

to take - a cauldron, or a good bronze

tripod, or two mules, or a golden cup

(Od. 15.82-85).

What makes the reception of the poor 'beggar' by Eumaios and Penelope ${ }^{27}$ all the more striking and impressive is the fact that in this case reciprocity is out of the question. Their guest will never entertain or give them gifts in return. Their only possible motives for treating with respect a dirty, tattered old tramp are regard for the gods, humanity, and a sense of compassion, arising from the host's own knowledge of suffering.

I stated earlier in this paper my view that the Odyssey was composed against an eighth-century background of social and political turbulence; that, as a poem composed for performance, the epic had to engage with the concerns of its audience; and that this audience consisted of wealthy elite, and poor, non-elite persons alike. On the basis of the passages of the Odyssey I have discussed, I would suggest that there are potentially radical notions of human equality and solidarity among men contained within the narrative. When the poem keeps alluding to the mutability of fortune, which can suddenly make a poor man rich, or,

26 See e.g. Finley 2002:60-61, 'It may be stated as a flat rule of ... archaic society that no one ever gave anything, whether goods or services or honours, without proper recompense ... to himself or his kin'.

27 Donlan 1982:148 classifies this sort of reception of 'have-nots' by 'haves' as '[o]bligatory or altruistic hospitality'. 
more often, a rich man poor, it seems to suggest that good character is not based on status as defined by either wealth or poverty. And indeed, this is what the epic shows us through speech and action - that wealthy, elite persons can be good, like Penelope, or bad, like the rapacious, cruel suitors (think of the very wealthy but also 'lawless' Ktesippos); and poor men may be bad, like the beggar Iros and the disloyal goatherd Melantheus, or good, like the herdsmen Eumaios and Philoitios.

Equally, when the Odyssey shows us the contrasting ways in which elite characters respond to the challenge posed by the presence of the destitute beggar, the poem seems to say something about the need for human solidarity. The narrative condemns the suitors' dismissive mockery and contempt for the poor, strongly contrasting it with Penelope's sympathetic generosity. The Odyssey indicates that the poor are not to be despised for being poor. It suggests that the proper response of the elite to those in need is one of pity and compassion, ${ }^{28}$ based on the understanding that suffering is part of the human condition, and that with a sudden stroke of fortune today's rich man might find himself tomorrow's beggar, and equally in need.

\section{BIBLIOGRAPHY}

Carr, B 1999. Pity and compassion as social virtues. Philosophy 74:411-429.

Crielaard, J 2009. Cities. In Raaflaub, K, Van Wees H (edd.), A companion to archaic Greece, 349-372. Chichester: Wiley Blackwell.

Dalby, A 1995. The Iliad, the Odyssey and their audiences. CQ 45:269-279.

Donlan, W 1973. The tradition of anti-aristocratic thought in early Greek poetry. Historia:145-154.

1982. Reciprocities in Homer. $C W$ 75:137-175.

Edwards, A 1993. Homer's ethical geography: Country and city in the Odyssey. TAPA 123:27-78.

Finley, M 2002. The world of Odysseus. New York: New York Review Books.

Graziosi, B 2002. Inventing Homer: The early reception of epic. Cambridge: Cambridge University Press.

Heubeck, A et al. 1988-1992. A commentary on Homer's Odyssey, 3 vols. Oxford: Clarendon.

Morris, I 1986. The use and abuse of Homer. CA 5:81-138.

2007. Early iron age Greece. In Scheidel, W, Morris, I, Saller R (edd.), The Cambridge economic history of the Greco-Roman world, 211-241. Cambridge: Cambridge University Press.

28 Cf. Rutherford 1986:156: 'the basic ethical framework of the Odyssey: rashness, boldness, overconfidence coming to grief; and, by contrast, the advocacy of generosity, mercy, gentleness'. 
Morris, I 2009. The eighth-century revolution. In Raaflaub, K, Van Wees, H (edd.), A companion to archaic Greece, 64-80. Chichester: Wiley Blackwell.

Nussbaum, M 1994. The therapy of desire: Theory and practice in Hellenistic ethics. Princeton: Princeton University Press.

Rose, P 1975. Class ambivalence in the Odyssey. Historia 24:129-149.

Rutherford, R 1986. The philosophy of the Odyssey. JHS 106:145-162.

Saïd, S 2011. Homer and the Odyssey (trans. from French by R Webb). Oxford: Oxford University Press.

Scodel, R 2005. Odysseus' dog and the productive household. Hermes 133:401408.

Scott, M 1979. Pity and pathos in Homer. AClass 22:1-14.

Strasburger, H 1997. The sociology of the Homeric epics. In Wright, G, Jones P (edd.), Homer: German scholarship in translation, 47-70. Oxford: Clarendon (=Studien zur alten Geschichte, i [Hildesheim 1982], 491-518).

Thalmann, W 1988. Thersites: Comedy, scapegoats, and heroic ideology in the Iliad. TAPA 118:1-28.

-1998. The swineherd and the bow: Representations of class in the Odyssey. Ithaca \& London: Cornell University Press.

Ulf, C 2009. The world of Homer and Hesiod. In Raaflaub, K, Van Wees, H (edd.), A companion to archaic Greece, 81-99. Chichester: Wiley Blackwell.

West, M 2011. The Homeric question today. Proceedings of the American Philosophical Society 155:383-393.

Whitaker, R 2017. The Odyssey of Homer: A Southern African translation. Cape Town: African Sun Press.

Whitley, J 1991. Social diversity in Dark Age Greece. ABSA 86:341-365. 